\title{
ANTICIPATING THE IMPACT OF NATURAL DISASTER ON FOREIGN TOURISTS THROUGH COLLABORATION IN THE CITY OF PARE-PARE
}

\author{
Muh. Rusdi \\ Makassar Tourism Polytechnic, Gunung Rinjani Street, Tanjung Bunga Makassar, Indonesia \\ Emai: rusdipoltekpar@gmail.com
}

\begin{abstract}
The purpose of this research is to build a collaboration between the travel business and the relevant government and the people of the City of Parepare in dealing with disasters. In addition, the parties who are members of the collaboration group carry out the stages of the safety process for tourists affected by the disaster to facilitate the handling of accident victims in the field. in the City of Parepare. Then this study, using a descriptive qualitative approach, the data collection techniques used are interviews, literature study, observation and documentation. The results of this study indicate that it is necessary to establish cooperation carried out by travel business parties to related sectors in the form of collaboration and the need for a soup or guide book to be made as a way to facilitate and understand the duties of each member of the cooperation group. are required to be able to equip their employees by adding skills and training, especially those related to First Aid in Accidents (P3K) this is important for travel businesses and related agencies to avoid more serious accident victims for tourists.
\end{abstract}

Keywords: Collaboration, Travel Business, Disaster, Accident Risk

\section{Introduction}

Indonesia is part of an archipelago that stretches from Sabang to Merauke. Its location is very strategic, and has a variety of tribes, cultures and customs, in addition to the friendliness of its residents which is a distinctive feature in distinguishing the Indonesian nation from other nations, its tourism potential is no less interesting when compared to other countries in the world.

However, currently, despite having cultural diversity and the readiness of destinations to bring in a number of tourists, there are obstacles because the overall condition of Indonesia's tourist destinations is experiencing a shortage of visitors, this is due to restrictions that prohibit the number of tourists from coming to visit more due to the pandemic.

From the impact of the restrictions issued by the government nationally, it will also have an impact on the entire existing tourism industry such as hotels, restaurants and travel businesses as well as other sectors related to tourism. Of course, what the government is currently doing is solely to break the chain of the spread of Covid-19 so that the amount of virus spread can be resolved quickly. 
South Sulawesi is a province that has natural beauty and tourist attractions that can support tourism development (Source: Central Statistics Agency of South Sulawesi). https://sulsel.bps.go.id/. With the various charms and beauty of the destination, it is like a complete package in presenting various things to be liked by tourism lovers, ranging from modern city life, peaceful rural atmosphere, to natural beauty that is still beautiful. Makassar as the capital city of South Sulawesi Province is the largest city in the Eastern Indonesia Region, and is the gateway for the entry of domestic and foreign tourists to this region.

By looking at the potential of very promising tourism destinations coupled with supporting facilities and other supporting facilities in South Sulawesi, one of the destination managers in the area, especially the City of Parepare, really allows tourists to come and enjoy the existing destinations, with more numbers but it is also necessary to understand that not all areas that have beautiful destinations and complete supporting facilities can guarantee the location is free from natural disasters.

Of the various kinds of disasters that may cause disasters and have an impact on tourists, especially on travel businesses, it is necessary to anticipate efforts from the Parepare City government, especially for travel business actors who are members of the ASITA organization which is one part of the government's partners in tourism administration including by involving related elements such as the government, the private sector and the community to jointly try to overcome the occurrence of disasters that can occur at any time in the City of Parepare.

Natural disasters such as earthquakes and flash floods and hurricanes cannot be predicted because they have always been natural disasters that have claimed many lives, material and non-material. Therefore, this research aims (1) to build collaboration between travel businesses in the City of Parepare with the relevant government in dealing with disasters. (2) To carry out a safety process for tourists (3) To increase the knowledge of travel business employees in providing emergency handling of tourists affected by disasters in the City of Parepare.

\section{Theoretical Review}

\section{Tourism}

According to Mathieson \& Wall in Gde et al. (2005), that tourism is an activity of temporarily moving people to destinations outside their place of residence and place of work and carrying out activities while at the destination and then preparing various facilities to meet their needs.

Tourism is often done by people, as a trip or traveling which in this case is synonymous with the word "reavel" in English. On that basis, the word "tourism" can also be interpreted as a trip made many times from one place to another which is also called "Tour".

Tourists who travel are generally organized by the tourism industry, especially those related to the sale of tour packages and the completeness of tourist documentation. This is contained in the development of the tourism industry which is contained in Law Number 10 of 2009 concerning tourism as follows:

Tourism business is a business that provides goods or services to meet the needs of tourists and the implementation of tourism and tourism entrepreneurs are people or groups of people who carry out tourism activities, while the tourism industry itself is a collection of tourism businesses that are interrelated in order to produce goods or services to meet the needs of tourists. in tourism management. The travel business that carries out its activities in the field by providing maximum service to tourists and is able to be responsible for the safety of the tourists it handles, including 
when a disaster or traffic accident occurs and so on (Syahrial, S., \& Badollahi, 2020; Nuong et al., 2021).

As for the risk for tourists from the impacts that can be caused by the travel business which usually occurs due to the use of transportation means such as cars and planes, most tourists do not clearly know the security facilities and the situation in the car or plane, they often have not read or understood the notice. in the event of a natural disaster, fire on board a bus or plane. when the fire broke out maybe the guests were fast asleep. Tourists who hear the news definitely can't hear the alarm, nor what other people say.

\section{Fire}

The fire broke out very quickly. One matchstick or one cigarette butt that has not really died, falls on the carpet, on a chair, bus or plane or in the forest can cause fatalities, besides fires occur due to short circuits that cause sparks or someone intentionally ignites fire for specific purposes such as sabotage, revenge, and others. Sometimes the flames spread widely in just a matter of minutes which need attention when there are blind tourists who have physical disabilities making it difficult to get out of the bus or plane, they should be assisted and prioritized (Bagyono et al., 2010).

\section{Safety}

Seeing the volume of tourists handled by the travel business which is quite high for the risks and responsibilities that are so great, the manager can as much as possible anticipate things that are not desirable and always ensure that the facilities are always in a safe and controlled condition when handling tourists. One of the most important things in handling the travel business is safety from the dangers of natural disasters or fires that threaten the means of transportation used by tourists at any time.

Although some people already understand the risks posed by fires in car vehicles that can cause sparks and fires due to electricity in the engine, some people still don't pay attention to it, so caution is needed by all parties to be able to increase their supervision (Sujatno, 2011)

\section{Definition of Disaster}

Disaster is an event or series of events caused by nature, humans and/or by both that result in victims of human suffering, loss of property, environmental damage, damage to facilities and infrastructure, public facilities, as well as those that can cause disruption to the life of tourists.

In essence, disasters caused by nature or due to human activities that result in displacement are disasters for the City of Parepare. So far, efforts to overcome them have been carried out in various ways by involving all components of society through coordination of handling from an early stage at the disaster location level in the region up to the provincial level.

Law Number 24 of 2007 concerning Disaster Management states that the definition of a disaster is an event or series of events that threatens and disrupts people's lives caused by natural factors and/or human factors resulting in loss of life, environmental damage, property and psychological impacts.

Disaster is an extraordinary event, beyond one's normal ability to deal with it, frightening and also threatening the safety of life. As a result of this disaster various important buildings were destroyed, casualties fell and affected the psychological condition of those affected by the disaster. Disasters often cause public panic and cause prolonged suffering and sadness, such as: injury, death, economic pressure due to loss of business or work and property, loss of family members and damage to infrastructure and the environment. 
Disasters that can disrupt the socio-economic life of the community caused by natural phenomena or human actions (Hidayati, 2005). In addition, according to Kodoatie \& Sjarief (2009), disaster is a disturbance or disorder in the pattern of life norms. Disturbance or chaos usually occurs in an unexpected way. Meanwhile, Haryanto (2001) states that disaster is the occurrence of damage to normal life patterns, is detrimental to human life, social structures and the emergence of community needs. Disasters can occur through a long process or certain situations in a very fast time without any signs.

Disasters often cause public panic that causes suffering and sadness and is prolonged, such as: injury, death, economic pressure due to loss of business or work and property wealth, loss of family members and damage to infrastructure and the environment.

From some of the definitions above, it can be concluded that a disaster is an unbalanced natural condition (wind, earth, water and fire) that causes damage, economic disruption, health decline, suffering and even death. Public.

\section{Types of Natural Disasters}

Natural disasters often occur suddenly and claim large numbers of victims. To know how to handle natural disasters, we must first know the types of natural disasters that can occur. From the Bakornas guidebook (2006) it is stated that the types of natural disasters include Earthquakes, Landslides, Floods and Typhoons or Hurricanes.

\section{Collaboration Concept}

Collaboration can be carried out when there is an element of joint involvement in a coordinated effort to solve problems together. Collaborative interactions are characterized by common goals, a systematic structure, by conducting high-level negotiations through interactivity and interdependence (Lai, 2011).

Thus, basically collaboration is not limited to a certain time or period as long as there are matters that have a relationship with other parties, collaboration is still needed, collaboration still involves several parties starting from the individual, work group, and organizational levels in carrying out collaboration, it is very important to understand performance as a public institution.

To understand the term collaboration in general which can be interpreted into two meanings of collaboration, namely in terms of regulating or managing both institutionally by involving nongovernment, this is in accordance with what was conveyed by Emirson who defines it broadly as the process and structure of a management in decision-making or public policy that engages the community constructively to achieve goals in other ways.

\section{Community Role}

Community is a group of people who are in the same geographic area and utilize local natural resources in the vicinity. In developed and developing countries, tourism is generally managed by the private sector with large business capital originating from outside the region and even abroad. So that local people who are in a tourism destination area cannot be directly involved in tourism activities. The non-involvement of local communities in tourism activities often leads to the opinion that local communities are not stakeholders

In accordance with the theory of Ansel and Gas 2007, explaining that collaborative governance is a government regulation in which one or more public institutions directly involve non-government stakeholders in formal collaborative decision-making processes. 


\section{Collaborative Plan Elements}

www.techniumscience.com

In general, a good plan contains or contains six elements, namely, the what, the why, the where, the when, the who, and the how, so a good collaboration plan must be able to provide answers to the questions that arise, as for the sixth the plan includes; (a) What actions should be taken for the travel business and related agencies....?; (b) why should this action be taken for the relevant sector?; (c) Where should the action be carried out by the relevant agency?; (d) When will the action be carried out by the related party?; (e)Who will carry out the action?; (f) How do the relevant agencies carry out the action?

From the questions mentioned above, it should be carried out by travel companies who collaborate with related parties in facilitating the implementation of activities in the field, then each related sector must be able to answer the existing questions so that the process of handling victims both in the form of accidents outside of natural disasters and those related to problems natural disasters can be resolved quickly (Manulang, 2012)

\section{Safety Procedure Stages}

In developed countries, the issue of health, safety and work security has always been an important issue that has been stated in the existing laws or regulations. The parties involved in the Joint working circle consistently carry out the rules that have been set with full awareness.

With the implementation of occupational health, safety and security standards, it is hoped that tourists can be protected from the possible risk of accidents, both caused by the work environment and the mistakes of the employees themselves when handling tourists. The travel company must ensure that the work environment and equipment used is safe. Therefore, it is the obligation of every company to provide training to its employees before carrying out their duties (Bagyono et al., 2010).

Consent that is considered given or implied, consent that is generally given in the patient's conscious state (normal). That is, the patient gives a signal to allow rescue action to be carried out on himself, and in an emergency situation, another situation is that the patient is unconscious or a small child who is unable to give consent to the child can also be asked for permission from the parents.

The obligations of first aid actors must be able to know; (a) Knowing vital signs; (b) Maintain the safety of self, team members, sufferers and those around them; (c) Can reach the patient; (d) Can identify and address life-threatening problems; (e) Request assistance or referrals; (f) Provide assistance quickly and appropriately based on the condition of the victim; (g) Assist other first aid actors; (h) Participate in maintaining the patient's medical confidentiality; (i) Communicating with other officers involved; (j) Prepare patient for transportation (Evacuation); (k) Knowing the signs of death (Basic First Aid Training, 2020).

\section{Presence of Leaders in the Company}

\section{Organizational Principles}

The existence of a leader in an organization requires the application of principles that aim to form a good organization or in an effort to compose an organization, so it is necessary to pay attention to or be guided by several organizational principles or principles carried out by a leader or manager in a travel business, namely; (a) Clear formulation of objectives; (b) Division of labor; (c) Delegation of power; (d) Level of supervision; (e) Unity of command and responsibility (Manulang, 2012). 


\section{The Role of a Manager}

It should be realized that the manager's position is a central position, the manager's position in the organization operating a travel business is the topmost level and it must be realized that the most important obligation for a manager is to make decisions (Sujatno, 2011).

\section{Human Resource Management}

A leader or manager also has obligations and responsibilities in terms of developing the capabilities of their employees, especially in facilitating employees who accompany tourists in providing assistance in the form of emergencies. However, the available natural resources are largely determined by the quality of human resources who play a role in planning, implementing and controlling the organization so that it can run well.

Travel businesses that anticipate the occurrence of risks to tourists during disasters, these employees need special training in order to be able to provide emergency assistance to tourists when there is a risk of accidents due to disasters (Manulang, 2012).

The authors hope in conducting this collaboration, namely how the travel business's efforts in collaborating with related sector parties, then how the steps should be taken by the travel business in carrying out the safety process, especially when a disaster or accident risk occurs.

And how are the efforts of the travel business in providing knowledge to employees, especially related to emergency rescue efforts before the authorities carry out these rescue actions. So that if this is fulfilled within the framework of thinking, there will be a handling of the risk of accidents and anticipating the emergence of more victims from tourists affected by the disaster.

\section{Methods}

In conducting this qualitative research, it does not use a population but a social situation which consists of three elements, namely place, actor and activity that interact synergistically (Spardly in Sugono 2006) so that the data sources of this study were obtained from interviews with stakeholders such as travel businesses, Parepare City Tourism Office, related BPBDs and observations of where these stakeholders are located. This study also uses simple quantitative research but still tends to be qualitative research. Data collection techniques using Literature Studies, Interviews and Documentation. While data analysis in qualitative research is more focused on the process of systematically studying and arranging interview transcripts, field notes, and other materials collected to increase understanding of these materials so that their findings can be presented to others (Bogdan, 1982). Miles \& Huberman (1994) mentions that data analysis during data collection takes the researcher back and forth between thinking about existing data and developing strategies for collecting new data. Data Analysis After Data Collection, At this stage the researcher is mostly involved in the presentation or display of the data collected and analyzed before qualitative researchers compose narrative texts. Display is a format that presents information systematically to the reader. 


\section{Results and Discussion}

\section{Development of International Tourists in South Sulawesi Province}

By looking at the development of tourism in Indonesia before the pandemic period showed extraordinary results because the Indonesian people today, are slowly experiencing a shift towards the needs of tourists, which are not only secondary needs, but have become primary needs. has become an important point for the development of other world tourism in South Sulawesi Province in the future.

However, South Sulawesi Province in the last three years has shown a decline in tourist visits, this can be seen in the table from 2018 to 2020 listed in table 1. below:

Table 1. Number of International and Domestic Tourists to South Sulawesi Province

\begin{tabular}{|c|c|c|c|}
\hline Year & Overseas Visit & Archipelago Visit & $\begin{array}{c}\text { Number of } \\
\text { Visits }\end{array}$ \\
\hline 2018 & 194.178 & 10.167 .715 & 10.361 .893 \\
\hline 2019 & 174.817 & 8.681 .275 & 8.856 .092 \\
\hline 2020 & 6.321 & 208.612 & 214.933 \\
\hline & & Total & $\mathbf{1 9 . 4 3 2 . 9 1 8}$ \\
\hline
\end{tabular}

Data Source: Provincial Tourism Office 2021

From Table 1. above, it shows a decrease in the number of tourist visits both foreign and domestic from 2018 to 2020 although this problem is almost felt by all companies engaged in tourism in the world today, so the government should have the ability to anticipating all forms of possibilities that are considered small but can have a big impact, especially in the tourism industry sector at both the central and regional levels.

To find out the number of visits by foreign and domestic tourists in the last two years in Parepare City, developments have not been maximized due to the corona outbreak conditions and government policies that limit people from gathering in large numbers and even ban tourist visits from other countries to Indonesia so that from this policy it will affecting entrepreneurs in the tourism industry, especially in the management of tourist destinations which resulted in an increasing number of Tourist Destinations (DTW) which experienced a decrease in the number of visitors who gradually DTW would experience closure. This can be seen in the data on tourist visits to the City of Parepare in table 2 . below

Table 2. Number of Foreign and Archipelago Tourist Visits to Parepare City

\begin{tabular}{|l|c|c|c|}
\hline Year & Overseas & Archipelago & Number of Visits \\
\hline 2017 & 1.299 & 737.761 & 739.060 \\
\hline 2018 & 1.156 & 750.153 & 751.309 \\
\hline 2019 & 2.073 & 768.421 & 770.494 \\
\hline 2020 & 1.018 & 52.657 & 53.675 \\
\hline 2021 & 191 & 4.821 & 5.012 \\
\hline \multicolumn{2}{|l}{ Total Visits } & $\mathbf{2 . 3 1 9 . 5 5 0}$ \\
\hline
\end{tabular}

Data Source of Parepare City Tourism Office 2021 
From the tourist visit data shown in the table. 1.3. This shows that the number of tourists who visited before the Corona outbreak showed increasing results both in the number of foreign and domestic tourists with foreign exchange earnings, especially in 2017 to 2018 so that it had a big influence and the position of the tourism sector at that time was very calculated when compared to other sectors.

However, according to Fardani as Head of Marketing and Market Analysis of Parepare City, he said that the increase in the number did not last long because once the pandemic occurred at the end of December 2019 until 2021, it showed a very significant decline, this was due to the prohibition of foreign tourists from entering Indonesia and the existence of a ban on foreign tourists entering Indonesia. activity restrictions, including the temporary closure of destinations that result in the number of domestic tourists also not being able to enjoy their vacations.

With this corona outbreak, which cannot be predicted far in advance, of course, the government has made this disaster as a learning material, including other threats that can affect the development of tourism going forward, so it is necessary to anticipate which can be used as one of the great opportunities to visit, especially if the City of Parepare has the potential a quite unique and varied destination and with the emergence of the Ainun Habibi event as one of the tourism icons in this city.

\section{Disaster Type}

Natural disasters that often occur in the City of Parepare and cause casualties and cause material losses in large numbers. For this reason, before knowing how to handle natural disasters, it is better to first know the various types of natural disasters and their explanations can be seen in table 1.3. the following:

Table 3. List of Disaster Types

\begin{tabular}{|c|c|c|}
\hline NO. & Types of Disaster & Description \\
\hline 1. & Earthquake & There is a shift in the interior of the earth. \\
\hline 2. & Tsunami & $\begin{array}{c}\text { A series of ocean waves with a fairly long } \\
\text { period caused by disturbances from the } \\
\text { seabed. }\end{array}$ \\
\hline 3. & Landslide & $\begin{array}{c}\text { Landslides are the movement of slope- } \\
\text { forming materials in the form of rocks, } \\
\text { debris, soil }\end{array}$ \\
\hline 4. & Flood & $\begin{array}{c}\text { Flooding in a general sense is a very high } \\
\text { amount of river water flow }\end{array}$ \\
\hline 6. & Drought & $\begin{array}{c}\text { The relationship between the availability } \\
\text { of water, which is far below the } \\
\text { necessities of life. }\end{array}$ \\
\hline & Hurricane/Hurricane & $\begin{array}{c}\text { is a vortex of strong winds with wind } \\
\text { speeds of } 120 \text { km / h or more that often } \\
\text { occurs in the tropics between the north } \\
\text { and south equinoxes }\end{array}$ \\
\hline
\end{tabular}

Data Source: BNBD City of Parepare 2021 


\section{Travel agent}

By looking at the types of disasters that may occur in the City of Parepare, the travel business needs to coordinate with the relevant government parties including involving the community in the City of Parepare to provide the best service for every tourist from arrival until the tourist leaves the City of Parepare. The existence of this travel, has full obligations and responsibilities in providing services while protecting tourists from various types of disasters including natural disasters that occur.

Natural disasters that occasionally hit the City of Parepare such as floods and hurricanes, fires are sometimes unpredictable, so we need to remain vigilant, including the outbreak that Indonesia is currently facing, namely the corona virus. The existence of a travel business in Parepare City amounts to 9 companies that play an important role in handling tourists, which can be seen in table 1.6 below:

Table 4. List of Travel Bureaus in Parepare

\begin{tabular}{|l|l|l|}
\hline No. & \multicolumn{1}{|c|}{ Company Name } & \multicolumn{1}{|c|}{ Company's address } \\
\hline 1. & PT. An-Nur Maaruf & Jenderal Sudirman Street \\
\hline 2. & EL. HJJ. Manajemen & Perumnas No. 42 Street \\
\hline 3. & PT. Suci Amanah Insani & Bau Maseppe No. 175 Street \\
\hline 4. & PT. Farham Surya Indah & Mattirotasi No. 177 Street \\
\hline 5. & PT. Asnita Mega Wisata & Latasakka Street \\
\hline 6. & PT. Larisa Nirwana Utama & Usman Isa Street \\
\hline 7. & PT. Salsabila & Pelita Tenggara Street \\
\hline 8. & PT. Bintang Metro Bahagia & Abdul Kadir Street \\
\hline 9. & PT. Abadi Pola Citra Mandiri & A, Cammi No. 108 Street \\
\hline
\end{tabular}

Data Source: Parepare City Tourism Office

By looking at the number of tourist travel businesses in the City of Parepare as shown in table 1.4. then this travel business, has a fairly large task and responsibility in protecting tourists from various disasters that may occur and have a direct impact on tourists so that it can result in the risk of accidents for that it is necessary to make efforts not only from the travel business but also other sectors and communities in the city. Parepare needs to take steps to participate in protecting tourists from accidents caused by disasters and initiatives are needed to make breakthroughs in coordination and cooperation with related parties.

\section{The Importance of Collaboration}

Development problems in the City of Parepare from time to time are not only felt to be lighter and easier, in fact the City of Parepare is actually faced with conditions that are increasingly difficult, complex, dynamic, and diverse in line with the level of needs, welfare, and progress of the people of Parepare City itself. . Such conditions are not only experienced by the city of Parepare but also in other areas in Indonesia.

The trend of shifting socio-political interactions between the government and related sectors in the government can be seen through the increasing role of the private sector and non-governmental organizations in carrying out tasks and responsibilities that were previously the monopoly of the government or the public sector.

This fact from one side is a new development that needs to be observed in an effort to improve services to tourists. But on the other hand, this shows the fact that there is a limited capacity of the existing apparatus in the government or other sectors to fulfill various public services. As a consequence, the government needs to innovate new public administration policies and practices 
and be able to respond to the challenges of the development of social and political interactions, through effective collaboration or collaboration with the private sector and the community.

With various obstacles that can be caused by disasters that have a direct impact on tourists to travel in the City of Parepare or tourists visiting other districts that pass through the city of Parepare, it is very important for travel businesses in this case the ASITA organization of Parepare City to immediately take steps in an effort to prevent the risk of accidents caused by the disaster.

The collaboration that has been carried out so far according to Mr. Rusli as the Chief Executive of the Regional Disaster Management Agency for the City of Parepare and also Mr. Muhidin as the Secretary of the Tourism Office of the City of Parepare and the leader of the travel business represented by PT. Suciamanah Insani Tour \& Travel Parepare City conveyed information that in relation to the cooperation between the travel business and the government and related sectors, there has never been a collaboration.

Meanwhile, the number of tourists visiting the city of Parepare and the types of disaster events and the number of accidents due to disasters. The types of incident data obtained from the PNBD of the City of Parepare that disasters that often occur in this area can be seen in the following table:

Table 5. List of Disaster Events in Parepare

\begin{tabular}{|c|c|c|}
\hline No. & Types Of Disaster & Description \\
\hline 1 & Landslide & BPBD \\
\hline 2 & Strong winds & \\
\hline 3. & Fallen tree & \\
\hline 4. & Flood & \\
\hline 5. & Fire & \\
\hline
\end{tabular}

Data Source BPBD Parepare 2021

Meanwhile, the amount handled by the Parepare City Regional Disaster Management Office from year to year can be seen in the following table:

Table 6. Number of Annual incidentsin Parepare

\begin{tabular}{|l|l|c|}
\hline No. & Year & Number of incidents \\
\hline 01. & 2018 & 114 \\
\hline 02. & 2019 & 97 \\
\hline 03. & 2020 & 1.138 \\
\hline
\end{tabular}

Data Source: BPBD Parepare City.

So there needs to be an initial step that must be taken to anticipate the occurrence of something that can suddenly occur such as an unexpected disaster and can threaten the existence of tourists in the destination area of Parepare City. a form of collaboration by involving related sectors such as the Tourism Office, Travel Business, BMKG, Hospitals, the TNI and Polri Security, BPNB based in South Sulawesi Province and BPBD Parepare City and other organizations directly involved in humanitarian social organizations such as the Nature Lovers Student (Student Cinta Alam). MAPALA) and the local community at the accident site. 


\section{Collaboration}

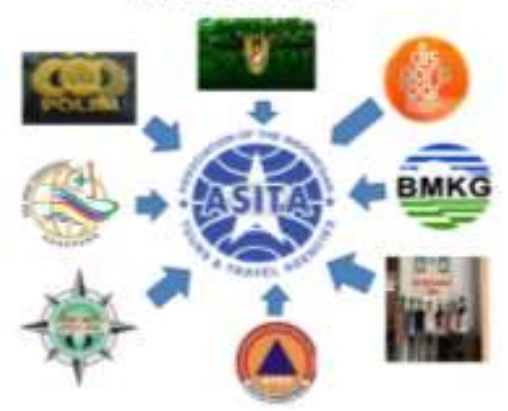

Figure 1. ASITA and related sectors in the city of Parepare

Author source 2021

In this effort to collaborate, increasing coordination in solving problems together is very necessary because collaboration interactions are characterized by common goals, a systematic structure, by conducting high-level negotiations through interactivity and by interdependence.

Thus collaboration is not limited to a certain time or period as long as there are matters that have a relationship with other parties, collaboration is still needed, collaboration can involve several parties starting from the individual, work group, and organizational levels in carrying out collaboration, it is very important to understand its performance as a public agency.

The meaning of the existence of this collaboration is to regulate or manage both institutionally by involving the government and other relevant sectors, processes and structures of a management in decision making or public policies that involve the community constructively to achieve goals in other ways.

The existence of the government which is related to other sectors related to disaster management in saving tourists visiting the city of Parepare from the risk of accidents so that it can ease the burden of travel efforts in providing safety assistance as one of the responsibilities that must be carried out optimally for tourists visiting the city of Parepare.

The purpose of the collaboration is to create or implement public policies in managing public programs or assets in order to address complex problems more precisely and quickly and based on a strong network. In collaborative cooperation, each party is bound by a common interest to find solutions to certain problems or issues, which are felt by all parties that can interfere with their interests. willingness to cooperate arises because of the desire to find solutions to problems that are shared by a public organization with its partners.

Both feel that these problems or interests can be solved more easily if they work together to find solutions to common problems or interests that become a source of inspiration and motivation for the development of collaboration between public organizations and community organizations.

\section{Safety Stage}

In developed countries, occupational health, safety and security in organizations that are incorporated in the form of collaboration has always been an important issue and is listed in laws or regulations that remember. The parties involved in the work circle consistently carry out the rules that have been set with full awareness.

By implementing occupational health, safety and security standards, each organization that is part of the collaboration is expected to be able to provide the best service for tourists and have the 
ability to be protected from possible risks of accidents caused by disasters. If you make a mistake then the travel company will tarnish its good name.

Thus, travel businesses and related agencies in collaborative activities must ensure that the work environment and equipment used are safe. Therefore, it is the obligation of every company and organization to provide training to its employees before carrying out their duties.

If the company leadership has provided training related to handling tourists who are affected by accidents when a disaster occurs, they can provide maximum initial assistance. That is, the patient gives a signal to allow rescue action to be carried out on himself, and in an emergency situation, other circumstances in which the patient is unconscious or a small child who is unable to give consent to the child can also be asked for permission from the parents.

The obligations of first aid actors must be able to know; (a) Knowing vital signs; (b) Maintain the safety of self, team members, sufferers and those around them; (c) Can reach the patient; (d) Can identify and address life-threatening problems; (e) Request assistance or referrals (f) Provide assistance quickly and appropriately based on the victim's condition; (g) Assist other first aid actors; (h) Participate in maintaining medical confidentiality, the patient has the right to communicate with other officers involved; (i) Prepare patient for transportation (Evacuation); (j) Knowing the signs of death.

\section{Leadership Policy}

The existence of leaders in every organization that is part of the collaboration in the City of Parepare can provide opportunities for employees, especially those related to the problem of ability to master their respective duties.

These organizations must be able to master their respective fields in general and in particular be able to understand the science of tourism because this is related to tourist safety and problems that occur to tourists when a disaster occurs which results in the fall of accident victims that lead to death and other regulations. related to it. this can only be done when the increase in Human Resources (HR) has been carried out to the maximum by the leadership of the agency in the organization as for the form of HR development that can be provided such as by providing opportunities for employees through various trainings.

The leaders of travel business companies who are members of the ASITA of Parepare City should be able to coordinate with the government and related sectors about what steps and procedures must be carried out when a disaster occurs and how to save tourists who are affected by accidents, so to be able to handle this properly. In this collaboration, travel businesses should immediately propose to provide training for each relevant agency that is part of the collaboration.

Then bring in experts to make procedures for handling accident victims due to disasters which are contained in the form of SOPs or making guidebooks, for example when a disaster strikes tourists, who can provide initial assistance and then it is carried out by other related sectors so that there is no overlap when carrying out emergency assistance. For example, those who are earlier in providing assistance are travel business employees who accompany tourists and then ask for help from the community around the destination.

Furthermore, the travel company reported to the government in this case the related sector, including by utilizing the tourism police in the City of Parepare to get faster handling. With the division of tasks contained in SOPs or guidebooks related to how to handle disaster victims for tourists, it can be resolved more quickly and properly so that the image of tourism in the City of Parepare through services provided when a disaster occurs can be more reliable. 


\section{Conclusion}

www.techniumscience.com

The existence of a travel business as the spearhead of the Parepare City government in increasing the number of tourist visits, as well as being a partner of the government in terms of helping to provide services and handling and being responsible for tourist safety, from arrival to return of tourists to their respective countries of origin, so it is necessary to anticipate every event that may occur through collaborative efforts in the City of Parepare. Tourists who are affected by the disaster, of course, need stages or procedures made by the travel business, whether in the form of SOPs or in the form of guidebooks so that they can provide assistance to tourists through collaboration or collaboration in accordance with the expertise of their respective tasks. Travel Business Leaders are fully responsible for the tourists they handle so they need to anticipate and prepare their employees to receive training, especially related to tourist safety, this is necessary because when the location of tourists affected by a disaster is likely to be far from the center of government, emergency handling is needed while waiting for further assistance. from related parties.

\section{References}

[1] Bagyono, T., Suwarni, A., \& Sudaryanto, S. (2010). Survei Pasar Kerja dan Animo Masyarakat untuk Kuliah di Jurusan Kesehatan Lingkungan. Sanitasi: Jurnal Kesehatan Lingkungan, 2(4), 146-151.

[2] Bakornas P. B, (2006). Panduan Pengenalan Karakteristik Bencana dan Upaya Migitasinya di Indonesia, Sat Bakornas PBP. Jakarta

[3] Bogdan, R. B. (1982). SK Qualitative research for education. Boston, Allyn and.

[4] Gde, P., Pitana, P., \& Gayatri, G. (2005). Sosiologi Pariwisata. Andi: Yogyakarta.

[5] Haryanto, H. S. (2001). Manajemen Penanggulangan Bencana. Bandung: Pionir Jaya.

[6] Hidayati, D. (2005). Panduan Siaga Berbasis Masyarakat. Jakarta: LIPI Press

[7] Kodoatie \& Sjarief. (2009). Pengelolaan Bencana Terpadu. Bandung: Nuansa Aulia

[8] Lai, E. R. (2011). Critical thinking: A literature review. Pearson's Research Reports, 6(1), 40-41.

[9] Manulang. M, (2012). Dasar-Dasar Manajemen.Yogyakarta: Gadjah Mada University Press.

[10] Mathieson \& Wall (1982). Dalam Pitana dan Gayatri (2005)

[11] Miles, M. B., \& Huberman, A. M. (1994). Qualitative data analysis: An expanded sourcebook. sage.

[12] Nuong, L. N., Trang, N. T. H., Trang, N. T. T., \& Lam, N. T. (2021). Developing Rural Tourism with the Participation of Related Parties in Bac Kan Province. Journal La Bisecoman, 2(1), 13-22. https://doi.org/10.37899/journallabisecoman.v2i1.332

[13] Syahrial, S., \& Badollahi, M. Z. (2020). Development of a Community-Based Marine Tourism Attraction in the Samboang Beach in Bulukumba Regency. Journal La Bisecoman, 1(2), 1-9. https://doi.org/10.37899/journallabisecoman.v1i2.83

[14] Sujatno, A. B. (2011). Hospitality; Secret Skill, Attitudes, and Performances for Restaurant Manager. Andi: Yogyakarta. 